\title{
Somali Refugee Solutions in Kenya: Challenges of Repatriation and Prospects of Local Integration.
}

\author{
Dr. Peter K. Kirui \\ Department of Humanities Education, School of Education, \\ University of Eldoret, Kenya. \\ Dr. Hellen S. Wanyonyi \\ Department of Humanities Education, School of Education, \\ University of Eldoret, Kenya. \\ Dr. Naomi Kutto \\ Department of Humanities Education, School of Education, \\ University of Eldoret, Kenya.
}

\begin{abstract}
This paper assesses the challenges of voluntary repatriation of Somali refugees in Kenya and the prospects of local integration, if considered. It aims to demonstrate that no one refugee solution is adequate and that all available options ought to be pursued concurrently for optimum results. Based on review of existing literature, the paper traces the trajectory of Somali refugees in Kenya amidst a continually restrictive space for refugees among host states like Kenya. While the tripartite agreement on voluntary repatriation has seen many Somali refugees voluntarilly repatriate, many challenges abound and a majority yet to repatriate.This therefore calls for an assessment of other refugee solution options, like local integration.It concludes that repatriation, resettlement and local integration, all provide options for a comprehensive Somali refugee solution in Kenya.
\end{abstract}

Key words: Somali, refugee, repatriation, local integration

\section{INTRODUCTION}

Somali refugees have resided in Dadaab refugee camps in north-eastern Kenya since 1991. For the nearly three-decades of encampment and restricted movement of Somali refugees, they have been hindered from effectively contributing to the Kenyan state socio-politico-economic development processes. While there are generally three solutions to the refugee problem: integration to first host country, resettlement in third country(often developed country)and the generally preferred repatriation to home country, Kenya has encouraged repatriation of Somali refugees and has not considered integration as an option. Except for the very few lucky refugees enrolled for resettlement in developed countries, the majority of Somali refugees are condemned to the restricted and often unproductive life at the refugee camps. Considering that global refugee estimates indicates that only about 1\% benefit from resettlement in a third country, this suggests that a majority of Somali refugees (99\%) are left with no option but stay in the enclosed refugee camps or repatriate to country of origin. Repatriation, however, is only possible when conditions at home have improved to allow for a dignified return. This paper, explores the above three possible solutions to the Somali refugee problem in Kenya explaining how they are mutually reinforcing and why they need to be pursued concurrently. Although local integration of Somali refugees is not, in practice, part of Kenya government refugee policy, 
this paper explores the potential benefits of integration in resolving the Somali refugee problem.

\section{Problem statement}

Host states like Kenya find themselves pushing for repatriation are preferred solution to the refugee problem. However, repatriation is only possible if conditions at home country have improved to allow for a dignified return. The tripartite agreement on voluntary repatriation signed in November $10^{\text {th }} 2013$ has only managed to repatriate $25 \%$ of refugee in the last five years. Many Somali refugees feel Somalia is still too fragile for return explaining the low numbers that chose to return. The volatile security situation in Somalia and the unwillingness of majority Somalis to return dashes any hopes of a solution in near future. Refugees who have been in the camps for a long time may also find it difficult to cope in their home countries in case they return. This, then, calls for a consideration of integration and advocating for more resettlement opportunities to willing developed states as part of burden sharing. The almost three-decade protracted Somali refugee situation in Kenya means relying on one solution is inadequate and results uncertain.

\section{Objectives of the paper}

1. Explore the development of Somali refugees in Kenya.

2. Describe the refugee solutions of repatriation, local integration and resettlement as applied in Kenya.

3. Examine the problems and prospects of repatriation, local integration and ressettlement in context of Somali refugees.

\section{Reflection on methodology}

Academic literature, documents from United Nations High Commissioner for Refugees (UNHCR) and Government of Kenya (GoK) are among the literature that will be used to consolidate the arguments in this paper. My experience as a humanitarian worker at Dadaab camps between 2009 and 2012 helps me in putting the discussion in context. Although this paper aims at exploring the prospects of the three refugee solutions in the case of the Somali refugees in Kenya, its analysis involves Kenyan-Somalis, Somali refugees and Somalians. This is intentionally meant to avoid the limitations of discussing the Somali refugee problem in isolation when the reality is historically connected and complex.

\section{The history of Somali refugees in Kenya}

Somali refugees fled to Kenya when the then president of Somalia Siad Barre was ousted in 1991 and the country plunged into a civil war (Ikanda, 2018). Since then, conflict in Somalia has been evolving with different actors fighting for control of state machinery. As a neighbouring country, Kenya (which also is home to significant populations of Somali ethnic group) has been hosting thousands of Somali refugees fleeing the raging conflict in Somalia. Since 1991, Kenya has pursued an encampment policy where Somali refugees are restricted to Dadaab refugee camps. The Kenya Refugee Act number 13 of 2006 and revised in 2014 expressly states that every refugee and asylum seeker shall "not leave the designated refugee camp without the permission of the Refugee Camp Officer" (Article 14[c]). Movement passes are issued by the government of Kenya through the Camp Officer to refugees who have reasons to move out of the refugee camps for educational, medical and other purposes. Because of the isolated and restricted camp, Somali refugees have not integrated into the Kenya population. Although the Kenyan population surrounding these camps is also ethnic Somalis, integration is minimum. 
Encampment as a refugee policy was introduced in Kenya when the Somali refugee crisis arose. This is because there had been no massive refugee influx before the Somali refugee crises and a few refugees from neighbouring countries could easily integrate with the local community. The historical relationship between Somalia and Kenya that is not so rosy has also affected the manner in which Somali refugees are treated or perceived. Kenya's military hot pursuit of Al Shabaab inside Somalia from mid-October 2011, and the retaliatory attacks by the militia in Kenya has intensified stigmatization of Somalis as "terrorists" 1 . Because of this, the Somali refugees in Kenya became the image of "terrorists" and calls for their repatriation gained momentum. These retaliatory attacks by Al Shabaab also rekindled memories of the Shifta War of the 1960's when Somalis in Kenya, with the help from Mogadishu, unsuccessfully fought to secede and join Somalia (Whittaker, 2012). However, human rights defenders like Amnesty International in their report ${ }^{2}$ dismiss indiscriminate condemnation of Somalis as scapegoat by GoK for their failure to contain insecurity in the country.

\section{REFUGEE SOLUTIONS AND APPLICATIONS IN KENYA}

The three refugee solutions are all applied in Kenya either directly or indirectly. Repatriation remains the most dominant or popular refugee solution. While local integration is not openly being practiced as a policy by the government, some Somali refugees has been integrated to the Kenyan society in many aspects like in economy, marriage, education among others. Few Somali refugees, about 1\%, have also benefitted from resettlement in third (developed) country such as USA, Australia, and Canada etcetera. In general, one refugee solution may work for some refugees and not others. For example, for a 25-year old refugee born in Dadaab refugee camp, repatriation may not be the best as they have no experience and attachment of their "home" country making reintegration much difficult upon return. In the following sections, I discuss these solutions individually and how it has applied in Kenya. Potential entry points especially for the often neglected integration are also highlighted.

\section{Repatriation: The legal framework and practice}

Repatriation means returning to one's home country. According to UNHCR's handbook for repatriation, repatriation must be voluntary and based on refugees' free choice to return ${ }^{3}$. Repatriation has been termed as the most preferred solution (especially by state actors) to the refugee problem (Lindley, 2011). UNHCR has indeed recognized that it is the most preferred but insists international community should collaborate to achieve this and must be voluntary ${ }^{4}$ (UNHCR, EC/SCP/41, 1985). One of the reason repatriation is preferred is because it allows for the restoration of citizenship in the country of origin (Lindley, 2011). Because it is often considered more "natural" to return home, it is perceived as less complex and not very much politicized. While repatriation is popular in Kenya's push for repatriation of Somali refugees, Lindley (2011, p. 16) warns that "aspiration to return refugees too easily becomes a rationale for the Government to avoid implementing measures to improve the protection and integration of refugees inside Kenya". In other words, romanticizing repatriation may make the host state neglect integration as a potential solution. For host states, repatriation seems the easiest way to avoid responsibility and political risks associated with integration.

\footnotetext{
${ }^{1}$ Heritage Institute for Policy Studies (HIPS). (2013). Hasty Repatriation: Kenya's attempt to send Somali refugees home. Mogadishu: HIPS

2 Amnesty International. (2014). Somalis are scapegoats in Kenya's counter-terror crackdown https://www.amnesty.be/IMG/pdf/somalis_are_scapegoats_in_kenya_s_counterterror_crackdown.pdf 3 UNHCR(2004). Handbook for repatriation and reintegration. Available at https://www.unhcr.org/partners/guides/411786694/handbook-repatriation-reintegration-activitiesemcomplete-handbookem.html

4 https://www.unhcr.org/excom/scip/3ae68cca4/voluntary-repatriation.html
} 
Kenya as a signatory to the 1951 United Nations (UN) Convention ${ }^{5}$ on the Status of a Refugee, the subsequent Protocol of 1967 and the 1969 OAU Convention ${ }^{6}$ governing specific aspects of refugees, it is bound by the legal obligations of these instruments. Among others, signatory states are forbidden from forceful repatriation of refugee in what the 1951 UN Convention calls the principle of non-refoulement. Nevertheless, refugee management is highly politicized and individual signatory states have variedly domesticated the conventions in their national legislations. Host states therefore seem to have freehand on refugees in their soils regardless of the general provisions of the conventions. Politics in host states determine legislations governing refugees including regulations on repatriation and when to cease refugee status. Indeed Menkhaus (2017) has cautioned that despite court rulings that have prevented GoK from closing down Dadaab refugee camps, the government still has means to create "push" factors so as to induce return.

In Kenya, refugee affairs are governed by the Refugee Act $^{7}$ no. 13 of 2006 . While this Act expressly forbids expulsion of refugees in Kenyan soil when they risk persecution at home, it provides situations when the GoK may invoke cessation clause that terminates ones refugee status. For example, Article 5(e) of Refugee Act 2006 states that a person shall cease to be a refugee if that person "can no longer, because circumstances in connection with which he was recognized as a refugee have ceased to exist, continue to refuse to avail himself of the protection of the country of his nationality". This therefore means that Kenya can invoke the cessation clause by simply claiming that Somalia is now safe for return. Although refugees are persons of concern to the UNHCR, they are subject to Kenyan laws. UNHCR being an agency of the UN is itself a creation of state actors and may not wish to antagonize them as they implement their mandate. The unwillingness of many states to equally share refugee burden means host state has relatively more powers to determine the fate of refugees regardless of presence of UNHCR as international custodian of refugee welfare.

\section{Repatriation as national security concern?}

Like many host states, Kenya has insisted that repatriation is the best option for the Somali refugee problem in Kenya. Kenya's preference for repatriation of Somali refugees is also informed by Kenya's suspicious relationship with Somalia that is often characterized by mistrust -first during Shifta War in the 1960's and recently threats from militia group Al Shabaab. Kenya's increased push for repatriation intensified after the Linda Nchi military campaign launched mid-October 2011 and led by Kenya Defence Forces (KDF) in hot pursuit of Al Shabaab militia inside Somalia. This attracted retaliatory attacks by Al Shabaab inside Kenyan soils as militia sought to erode Kenya's military victory in southern Somalia (Anderson \& Mcknight, 2014). During these retaliatory attack in Kenya by Al Shabaab, GoK has insisted that the planning and execution of some of these attacks are done at the Dadaab refugee camps by armed refugees or people disguising themselves as refugees.

\footnotetext{
5 UN Convention and Protocol Relating to Status of Refugees. Available at: https://www.unhcr.org/protection/basic/3b66c2aa10/convention-protocol-relating-status-refugees.html ${ }^{6}$ OAU Convention, Governing Specific Aspects of Refugee Problems in Africa, $10^{\text {th }}$ September, 1969. Available at: https://treaties.un.org/doc/Publication/UNTS/Volume\%201001/volume-1001-I-14691-English.pdf

7 Refugee Act no. 13 of 2006 . Available at

https://www.google.com/url?sa=t\&rct=j\&q=\&esrc=s\&source=web\&cd=1\&ved=2ahUKEwjN1K-

yzpHiAhXLa1AKHU7pCQoQFjAAegQIAhAC\&url=http\%3A\%2F\%2Fkenyalaw.org\%2Flex\%2Frest\%2Fdb\%2Fkeny alex\%2FKenya \%2FLegislation\%2FEnglish\%2FActs $\% 2520$ and $\% 2520$ Regulations $\% 2 F R \% 2 F R e f u g e e \% 2520$ Act $\%$ 2520Cap.\%2520173\%2520-

\%2520No.\%252013\%2520of\%25202006\%2Fdocs\%2FRefugeeAct13of2006.pdf\&usg=AOvVaw1pHUbj4wi0NoQr WI8xv_jE
} 
Although there is no concrete evidence as none of Somali refugee has been successfully prosecuted for these attacks, the GoK insists that it wants to close these camps because they are a "security challenge" and are an "existential threat" on Kenya. Of the many terrorists attacks by the Somali-based Al Shabaab militia, the West Gate Mall attack of 2013(Anderson \& Mcknight, 2014) and Garissa University attack ${ }^{8}$ of 2015 are among the worst of these attacks where both claimed more than 200 lives. Calls for repatriation of Somali refugees often intensify following such attacks with GoK officials leading the charge of blaming Somali refugees. Human Rights Watch (HRW) has, however, dismissed these GoK allegations and views them as mere scapegoating ${ }^{9}$ of Somali refugees (HRW, 2016).

These claims of Somali refugees being a threat to national security have been maintained since independence. According to Campbell (2006), Somali refugees were first accused of causing insecurity and later terrorism and competing with locals for the scarce economic opportunities. The tension between these two groups led to violent conflicts (Menkhaus, 2015).

In a bid to actualize repatriation, a tripartite agreement was signed between UNHCR, GoK and Somalia on $10^{\text {th }}$ November 2013 as framework for voluntary return. Those Somali refugees, who as of March 31, 2019 had been repatriated, according to UNHCR, were 83,03510 since the tripartite program rolled out in 2014. This number represents about $25 \%$ of Somali refugees in Kenya and the GoK has in many occasions expressed frustration on the slow pace of repatriation. Although Kenya has in many instances threatened to forceful close down the camp, it has never implemented it because of court injunctions and pressure from the international community. The GoK in March 2019 revisited calls to close down the Dadaab camps in the next six months with HRW ${ }^{11}$ and Amnesty International ${ }^{12}$ protesting the move on grounds it violates Kenya's commitment to international obligations. Time will tell how Kenya will respond to this.

Kenya's management of Somali refugees is mostly a political problem than a legal problem. This explains why Kenya insists on closing down Dadaab camps hosting thousands of Somali refugees yet it hosts thousands of South Sudanese refugees at Kakuma refugee camps. While indeed repatriation is a viable option when dealing with thousands of refugee, it is only possible when conditions at home have improved to warrant a dignified return. Premature and induced return may trigger or intensify conflict especially when state institutions in home country are weak. Its success is therefore based on stability in home countries of refugees and not whether host states can induce returns through "push" factors.

\section{DEVELOPMENT AND GENERAL CHALLENGES OF SOMALI INTEGRATION}

Local integration involves a legal process where refugees acquire a wide range rights in host state, an economic dimension of establishing livelihood comparable to host state residents and a social-cultural dimension where refugees adapt and are accepted in the social life of host

\footnotetext{
8 BBC, Kenya attack: 147 dead in Garissa university assault. Available at https://www.bbc.com/news/worldafrica-32169080

9 Human Rights Watch, 'Dispatches: Scapegoating Refugees in Kenya' www.hrw.org/news/2016/05/11/dispatches-scapegoating-refugees-kenya

${ }^{10}$ https://www.unhcr.org/ke/wp-content/uploads/sites/2/2019/04/Kenya-Statistics-Package-31-March2019.pdf

11 https://www.hrw.org/news/2019/03/27/kenya-reverse-move-close-refugee-camp

12 https://www.amnesty.org/en/latest/news/2019/03/kenya-must-not-force-refugees-back-to-somalia-byclosing-dadaab-camp/
} 
state (Crisp, 2004). The narrow conception of local integrations holds that local integration is considered a durable solution only at the point a refugee or asylum seeker becomes a naturalized citizen of the host state (Crisp, 2004). A broader multi-dimensional conception of local integration maintains that a refugee could actually acquire all the three dimensions of integration without necessarily being naturalized (Fielden, 2008). For purposes of this paper, local integration is broadly defined as acceptance of refugees as permanent residents of host state with relatively equal rights as citizens of host state regardless of whether they acquire citizenship or not.

Because local integration is not a practical solution when dealing with mass influx of thousands of refugees, it has not been given much attention compared to repatriation. This is because migrants (refugees) may cause tension or conflict between migrants and residents of host state (Fujibayashi \& Nakayama, 2017). Because of the less significance attached to integration as solution for refugees, local integration has been termed as the most neglected or forgotten solution to the refugee problem. One reason local integration is largely unrecognized, argues Fielden (2008), is because of being overshadowed by repatriation as most preferred option. Local integration is integrating refugees in first country of asylum. Integrations may involve the legal, cultural and socio-economic incorporation of refugees into the daily live of host state population (Kibreab, 1989). Even though encampment policy isolates refugees from societal participation hindering integration (Lindley, 2011), the increasing urbanization of refugee population could promote integration (Campbell, Crisp \& Kiragu, 2011)

Because of Kenya's relative stability, it has hosted refugees from neighbouring countries since the 1960's, initially preferring to locally integrate them (Abuya, 2007). Integration was at the time popular durable solution in Africa (Ahimbisibwe, Ingelaere \& Vancluysen, 2017) and many countries pursued an open-door policy towards refugees (Rutinwa, 1999). From the 1990's, however, Kenya has preferred repatriation as a solution to refugee problem and as such has no policy on refugee integration. Since then the earlier open-door policy was progressively replaced with a more restrictive one. While many reasons could have informed this change of policy, perhaps the multi-party wind of change that then swept across Africa and its subsequent political shake-up and accompanying mass displacement is one of the main reasons. Kenya, like many countries in Africa at the time, was struggling to manage local agitation for multiparty making local integration of refugees a risky adventure.

Kenya's North-Eastern Province (NEP) that until 1991 had been under state of emergency since the Shifta War (1963-1967), where Somalis in Kenya fought to join the Greater Somalia, only worsened Somali refugee prospects of integration. Because of the suspicion planted during the Shifta War, Kenya was not sympathetic to Somali (refugees) who were caught up in the communal victimization and forced repatriations (Lind et al., 2015).

Clan and family ties between Kenyan-Somalis and Somalians and the civil war in Somalia that is often fought along clan lines may have discouraged the GoK from considering integration. This is for fear that clan conflicts in Somalia could easily spill over to Kenya (Scharrer, 2018). Indeed clan conflicts in Somalia or Kenya have in several instances spread into Dadaab refugee camps and vice versa (Menkhaus, 2015). Integrating Somali refugees by implication (though theoretically) means risking conflict spillover from Somalia. This view could however be challenged by the fact that already Kenyan-Somalis have the same clans in Kenya.

Notwithstanding the family and clan ties of Somalis in Kenya and Somalia, the originally "one Somali nation" in pre-colonial Somalia has been greatly influenced and now differs significantly because of different characteristics of Kenya and Somalia states. This difference is not just at 
the level of state governance and ideals but to those of individual characteristics. In fact Scharrer (2018) established that Somali refugees think of Kenyan-Somalis as ignorant of Somali culture and language and that although they are their descendants, are not "real" Somalis. This implies that Somali refugees still have difficulties integrating with KenyanSomalis in spite of the common and often misleading view that Somalis are homogenous.

Besides that, the increasing influence of Kenya-Somalis in economic and political spheres in Kenya has led to increase in anti-Somali sentiments. Somalis, "Nubians" or Arabs, Asians and White Kenyans are perceived as "ambiguous" citizens (Scharrer, 2018). As a result, there are fears that Somalis "are taking over Kenya" or "Kenya is colonized by refugees" are common (Scharrer, 2018, p. 498). Increase in such often popular sentiments because of their political correctness in national discourse works against the possible integration of Somali refugees in Kenya. To ordinary Kenyans, there is no difference between Kenyan-Somalis and Somali refugees partly because of their relatively similar language, culture, religion and physical features.

The stigmatization of Somali refugees and Kenyan Somalis as terrorists and the subsequent calls for closure of Dadaab refugee camps stems from seeing Somalis are "foreigners" and ambiguous citizens (Scharrer, 2018). This blanket condemnation that challenges integration of Somali (refugees and Kenyans) limits the prospects that Somali refugees will be successfully integrated. The increased terrorist attack from 2011 has exposed Somali refugees to police harassment and extortion. The fact that many refugees are illiterate and do not speak Swahili, the national language in Kenya means they are subject to profiling and stigmatization especially by the security agents

Resources from international humanitarian agencies targeting refugees and not the host community also tend to further isolate refugees making integration difficult $\left(\mathrm{O}^{\prime}\right.$ Callaghan \& Sturge, 2018). This is partly blamed on UNHCR's quasi state role in managing refugees in camps and not in the local community (Gilbert, 1998; Slaughter \& Crisp, 2009).The fact that Dadaab is located at the remote arid North Eastern Province means the surrounding community is poor and is often affected by drought and famine.

\section{Resilience in Economic integration of Somali refugees}

Even though GoK has on many occasions insisted on repatriation, there is indeed hope that integration could be considered in the future. The Inter-Governmental Authority on Development (IGAD) on 25 th March 2017 signed the Nairobi Declaration on Durable Solutions for Somali Refugees and Reintegration of Returnees in Somalia ${ }^{13}$. If fully implemented, the "Nairobi declaration" in Article IV(6) proposes to facilitate "free movement of refugees and their integration into national development plans and access to services"14. This could signal a major shift in policy from that of solely encampment anticipating repatriation to one where integration is also an option.

Besides the "Nairobi declaration" that spells some hope of possible integration policy in future, a study in 2013 indicate that only about 2\% of Somali refugee in Dadaab depend solely on humanitarian assistance (Kamau \& Fox, 2013). In Kakuma ${ }^{15}$ refugee camp a Humanitarian

\footnotetext{
13 https://data2.unhcr.org/en/documents/download/58248

14 Nairobi Declaration on Durable Solutions for Somali Refugees and Reintegration of Returnees in Somalia, $25^{\text {th }}$ March 2017. Available at https://data2.unhcr.org/en/documents/download/58248

15 Kakuma is the second largest refugee camp after Dadaab. According to UNHCR, it was established in 1992 and is located in North-western Kenya hosting 186,692 as of end of November 2018.
} 
Policy Group (HPG) report observes that "Of those reporting a cash income, the largest source was from employment (36\%), followed by remittances (29\%) and business (20\%)" (O'Callaghan \& Sturge, 2018, p.19). An earlier study had put remittances at $30 \%$ followed by business and employment at 29\% and 28\% respectively (Refugee Consortium of Kenya, 2015). A relatively similar percentages could apply at Dadaab. This shows that refugees are already largely economically integrated in the economy despite the restricting nature of encampment in terms of where they can work, nature and scale of their economic engagement.

Refugee who have fled the harsh camp life and settled in urban centres tend to be economically prosperous and well off than those in the camps although this should not mean that they are well integrated to the Kenyan economy (O'Callaghan \& Sturge, 2018). Only very few hold the M class permit that allows them to be gainfully employed and many are underemployed (O'Callaghan \& Sturge, 2018). Many refugees find it difficult to get credit (Beversluis et al., 2016) for start-up capital and most of them rely on remittances from friends and relatives abroad, most of whom are beneficiaries of resettlement programmes.

In spite of the encampment policy that restricts refugees to the designated areas (Refugee Act, 2006), there are many Somali refugees who reside outside the refugee camps and mostly in Kenyan urban centres (Lindley, 2011) with the majority residing in Nairobi's Eastleigh. Although odds are against Somali refugees in their pursuit of self reliance, they are resilient and through their own agency managed to attain some level of self sufficiency that is not dependent on humanitarian assistance.

\section{Legal integration and law enforcement}

There is no legal policy framework that allows for integration of refugees in Kenya. The Refugee Act of 2006 envisages that refugees will reside in "designated areas" until the time that repatriation is feasible or when the cessation clause has been applied.

\section{Social-Cultural integration}

Somalis in Kenya and those in Somalia share a common ancestry. The common religion, language and other cultural aspects means Somali refugees could much easily integrate with Kenyan-Somalis. These common characteristics however do not imply that integration is expected to be seamless.

\section{RESETTLEMENT}

This involves integration in third country and is often a developed country. According to United Nations High Commissioner for Refugees (UNHCR), resettlement is the "selection and transfer of refugees from a State in which they have sought protection to a third State which has agreed to admit them - as refugees - with permanent residence status"(UNHCR Resettlement Handbook, 2011, p.3). Globally, resettlement in general only benefits 1\% of total refugee populations (Long, 2011) and therefore cannot be relied as a solution to the current 25.4 million refugees as of UNHCR data of May, 2019. Chances of getting resettlement are therefore so slim that Jacobsen (2005, p.55) equates to "winning a lottery". These global figures on resettlement are also reflected among Somali refugees in Kenya seeking to be resettled. For example in 2014, UNHCR submitted 4325 Somali refugees in Kenya for resettlement, and this comprised 1\% of Somali refugees in Kenya at the time (UNHCR refugee resettlement trends, 2015).

Although resettlement benefits only very few Somali refugees, many are attracted to it and look forward to that magical time of resettlement to one of the developed countries. According to one study by Ikanda (2018), there is a longing of Somali refugees to be resettled to 
Minnesota, USA, where a network of friends and relatives already exist. This is partly attributed to the harsh conditions at the Dadaab refugee camps (Horst, 2006) that limit refugees from exploiting their potentials. Because those resettled are given permanent residency, they enjoy rights like other nationals and could potentially benefit from being naturalized as citizens (UNHCR Resettlement Handbook, 2011). In spite of this, the UNHCR handbook warns that resettlement should not be viewed as an alternative migration route. Instead, UNHCR emphasizes repatriation and local integration as more viable options to the refugee problem (Ikanda, 2018).

Expanding resettlement programmes for willing and able countries could help in solving the refugee burden of host states. The developed world should perhaps consider increasing resettlement opportunities especially for refugees in protracted conflict situation. By targeting refugees in very long protracted refugee situations like those in Dadaab camps for 25 years or more, it will safeguard resettlement from being misused as an alternative route to migration.

\section{CONCLUSION}

This paper has explored the three refugee solution with reference to Somali refugees in Kenya. Because each refugee solution has its strengths and weaknesses, it has been argued that the three solutions: repatriation, local integration and resettlement should be pursued concurrently for optimum results.

This paper recommends that:

\section{RECOMMENDATION}

1. The three refugee solutions be pursued concurrently so as to take advantage of the strengths of each solution according to various refugee dynamics

2. The international community should cooperate more in sharing of refugee burden so as to ease burden of host states.

3. More research should target each refugee solutions in different refugee contexts to broaden our knowledge on what works best when and where.

\section{References}

Abuya, E.O. (2007). Past reflections, future insights: African asylum law and policy in historical Perspective. International Journal of Refugee Law,19, pp. 51-95.

Amnesty International. (2014). Somalis are scapegoats in Kenya's counter-terror crackdown https://www.amnesty.be/IMG/pdf/somalis_are_scapegoats_in_kenya_s_counterterror_crackdown.pdf

Anderson, D. M. \& McKnight, J. (2014). Kenya at war: Al Shabaab and its enemies in Eastern Africa. African Affairs, 114 (454), pp.1-27.

Beversluis, D., Schoeller-Diaz, D., Anderson, M., Anderson, N., Slaughter, A. \& Patel, R.B. (2016).Developing and validating the refugee integration scale in Nairobi, Kenya. Journal of Refugee Studies, 30(1), pp. 106-132.

Campbell, E., Crisp, J. \& Kiragu, E. (2011). Navigating Nairobi: A Review of the Implementation of UNHCR's Urban Refugee Policy in Kenya's Capital City, UNHCR Policy Development and Evaluation Service (PDES),

PDES/2011/01, Geneva: UNHCR, 2011, available at: http://www.unhcr.org/4d5511209.pdf (Accessed 8th May, 2019).

Crisp, J. (2004). The local integration and local settlement of refugees: a conceptual and historical analysis. New Issues in Refugee Research, Working Paper No.102, UNHCR: Geneva.

Fielden, A. (2008). Local integration: an under-reported solution to protracted refugee situations. New Issues in Refugee Research, paper no.158. Policy Development and Evaluation Service, United Nations High Commissioner for Refugees, Geneva.

Gilbert, G. (1999) 'Rights, legitimate expectations, needs and responsibilities: UNHCR and the New World Order' International Journal of Refugee Law, 10 (3), pp. 349-388 
Horst, C. (2006). Transnational nomads: How Somalis cope with refugee life in the Dadaab camps of Kenya . Oxford: Berghahn Books.

Fujibayashi, H. \& Nakayama, M. (2017) .An option to avoid the sudden mass influx of migrants resulting from worldwide environmental threats. International Journal of Social Science Studies, 5(6), pp.1-8.

Heritage Institute for Policy Studies (HIPS). (2013). Hasty Repatriation: Kenya's attempt to send Somali refugees home. Mogadishu: HIPS

Human Rights Watch (2016). Dispatches: Scapegoating Refugees in Kenya. www.hrw.org/news/2016/05/11/dispatches-scapegoating-refugees-kenya

Ikanda, F. N. (2018). Somali refugees in Kenya and social resilience: resettlement imaginings and the longing for Minnesota. African Affairs, 117(469), 569-591.

Jacobsen, K. (2005).The Economic Life of Refugees. USA: Kumarian Press Inc.

KenyaRefugee Act no.13 of 2006.

http://kenyalaw.org/kl/fileadmin/pdfdownloads/Acts/RefugeeAct_No13of2006.pdf

Kibreab, G. (1989). Local Settlements in Africa: A Misconceived Option? Journal of Refugee Studies, 2(4), 468-490.

Lind, J., Mutahi, P. and Oosterom, M. (2015) TangledTies: Al-Shabaab and Political Volatility in Kenya, IDS Evidence Report, No 130, Brighton: IDS.

Lindley, A. (2011). Between a protracted and a crisis situation: Policy responses to Somali refugees in Kenya. Refugee Survey Quarterly, pp.1-36.

Long, K.(2011). Permanent crises? : unlocking the protracted displacement of refugees and internally displaced persons. Policy overview, Oxford Department of International Development, Refugee Studies Centre, Oxford, UK.

Menkhaus, K. (2015). Conflict Assessment: Northern Kenya and Somaliland. Danish Demining Group.

http://dx.doi.org/10.2139/ssrn.2589109.

Menkhaus, K. (2017). Dadaab returnee conflict assessment. Danish Demining Group.

Nairobi Declaration on Durable Solutions for Somali Refugees and Reintegration of Returnees in Somalia, 25 ${ }^{\text {th }}$ March 2017. Available at https://data2.unhcr.org/en/documents/download/58248

OAU Convention, Governing Specific Aspects of Refugee Problems in Africa, $10^{\text {th }}$ September, 1969. Available at: https://treaties.un.org/doc/Publication/UNTS/Volume\%201001/volume-1001-I-14691-English.pdf

O'Callaghan, S. \& Sturge, G. (2018). Against the odds: refugee integration in Kenya. HPG Working Paper.

Refugee Consortium Kenya (2015). Myths and truths, livelihoods in Nairobi: the facts about refugee self sufficiency and economic contribution in Nairobi. Nairobi: RCK.

Rutinwa, B. (1999). The End of Asylum? The Changing Nature of Refugee Policies in Africa.

(Working Paper No. 5), UNHCR New Issues in Refugee Research , Geneva.

https://www.unhcr.org/research/working/3ae6a0c34/end-asylum-changing-nature-refugee-policies-africabonaventure-rutinwa.html

Scharrer, T. (2018). "Ambiguous citizens": Kenyan Somalis and the question of belonging. Journal of Eastern African Studies, 12(3), 494-513.

Slaughter A. and Crisp J. (2009) A surrogate state? The role of UNHCR in protracted refugee situations. New issues in refugee research. Research Paper No.168. UNHCR

UNHCR (2011). UNHCR resettlement handbook .Geneva.

UNHCR (2015). UNHCR refugee resettlement trends 2015. Geneva.

UNHCR, Data at a glance. Available https://www.unhcr.org/figures-at-a-glance.html

Whittaker, H. (2012). Forced villagization during the Shifta conflict in Kenya, ca. 1963-1968. International Journal of African Historical Studies, 45(3), 343-364. 